\title{
街区の空間特性が街路空間の風通し環境に及ぼす影響 \\ 気候資源としての風の利用を目的とした街路形態と街路空間の風通しの関係の分析 その 2 \\ EFFECTS OF CHARACTERISTICS OF URBAN BLOCK ON WIND ENVIRONMENT IN THE STREET CANYON
}

Analysis on the relationship between properties of urban block and wind path in the street canyon for the use of the wind as the climate resources Part 2

竹林英樹*, 山田俊明**, 森山正和***

\section{Hideki TAKEBAYASHI, Toshiaki YAMADA and Masakazu MORIYAMA}

\begin{abstract}
To promote ventilation in the street canyon is one of the effective urban heat island measures. The analysis on the relationship between properties of urban block and wind environment in the street canyon is required. In this study, relationship between wind environment in the street canyon and characteristics of urban block e.g. building cover ratio, variation of building heights, as well as roadside properties e.g. direction of street, width of street, height of building, is studied by CFD simulation results carried out in the central Osaka city. Ventilation in the street canyon is promoted by positive and negative pressure areas which are formed by variation of building heights. Both "the vertical wind path" caused by high-rise building and "the horizontal wind path" formed along the wide road parallel to upper wind direction should be considered for the improvement of ventilation in the street canyon. It is also confirmed that the attention to windward and downwind areas should be noted.
\end{abstract}

Keywords : Wind environment, Street canyon, Urban block, Urban heat island, Sea breeze 風通し, 街路空間, 街区, ヒートアイランド, 海風

\section{1.はじめに}

日本の多くの都市は沿岸部に位置しており, 夏季日中には海風に よる高温化抑制効果の恩恵を受けていると考えられる，ヒートアイ ランド現象に対する対策方法の一つとして, この海風を市街地内に 積極的に誘導することが検討されている，著者らは大阪市及びその 周辺地域を対象として, 地上から $50 \mathrm{~m}$ 程度の高さで観測された気温, 風向, 風速のデータを用いて海風の市街地気温緩和効果のポテンシ ヤルを評価した ${ }^{1)}$. その結果, 海岸から離れた地域 $(20 \mathrm{~km}$ 程度) で あっても, 海岸付近の風速の 4 割程度まで減衰するが上空に海風が 進入してきており, 地表付近の風通し改善のポテンシャルとして利 用することが可能であると考察された。このような背景のもと, 著

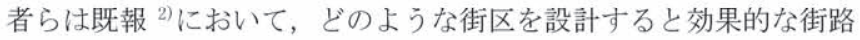
空間の風通しが得られるかとの観点から, 街路形態と街路空間の風 通しの関係を分析した. 日本建築学会では流体数值計算による風環 境評価ガイドライン作成WGにより「市街地風環境予測のための流体 数値解析の利用に関するガイドライン」が作成されており ${ }^{33}$, 本研 究では既報に引き続きこのガイドラインに沿って流体数值計算によ り市街地空間の風環境の計算を実施し, その結果に基づき街路形態
と街路空間の風通しの関係を分析する。

ヒートアイランド対策として, 市街地空間内の風通し環境の改善 を図る方策としては，例えば CASBEE-HI には風通しの項目がある. CASBEE-HI では敷地を取り囲む仮想閉空間を単位として外部環境へ の負荷を管理する立場が取られており，風通し環境の評価には地域 特性一の配慮が定性的に含まれているが，定量的な評価の指標とし て用いられる空地率, 卓越風向に対する建築物 (群)の見付面積比, 隣棟間隔指標は, それぞれ, 敷地面積, 敷地幅, 敷地境界からの距 離を基準として規定されている。これに対し，実際の市街地におけ る風通し環境は, 敷地境界からの距離ではなく, 隣接する敷地の建 築物との距離（道路などの公共のオープンスペースを含む）が支配 要因であり，グロス建蔽率などを用いて評価される ${ }^{4 \sim 7)}$. 一般に, ヒートアイランド対策の検討が必要とされる大阪市中心部などを想 定すると, 敷地毎の建蔽率は大きく, 風通しの指標となる隣棟間隔 はほぼ道路幅によって規定される場合が多い.このような観点より， 本報においても既報に引き続き，道路幅，建物高さ，主風向と道路 方向の関倸などを街区の空間特性の指標とし, 街路空間の風通しと の関係を分析する。

\footnotetext{
$*$ 神戸大学大学院工学研究科建築学専攻

准教授・博士 (工学)

** 関西電力株 $)$ 修士 (工学)

*** 摂南大学理工学部住環境デザイン学科 教授・工博
}

Assoc. Prof., Department of Architecture, Graduate School of Engineering, Kobe University, Dr. Eng.

The Kansai Electric Power Company, M. Eng.

Prof., Department of Living and Environmental Design, Faculty of Science and Engineering, Setsunan University, Dr. Eng. 


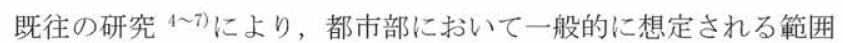
でグロス建蔽率が大きくなると地区全体の平均的な風通しが悪くな り，建物高さにばらつきがあると風通しが向上することなどが明ら かになっている. 本研究では, これらの検討結果を踏まえ, 街路形 態だけでなく幾つかの建築物により形成される街区の特性（グロス 建蔽率, 建物高さのばらつき, 高さ方向グロス建蔽率など）が風通 し環境に及ぼす影響を考察する. 併せて, 風上領域の街区特性が, 対象とする街区内の風通し環境に及ぼす影響についても考察する.

足永らは東京都心 $10 \mathrm{~km}$ 四方を対象に, 水平 $5 \mathrm{~m}$ メッシュ解像度で 地球シミュレータを用いた大規模数值解析を実施し, 超高層建物に より海風が遮断される様子などを考察している ${ }^{8)}$. 将来的には都市 域全体を対象とした高解像度の数值解析が実施され, それに基づき 具体的な風通し対策が検討されると想定されるが, 現状では容易に 実施できる状況でないため, 大阪市中心部を対象とした計算結果に 基づき,街区の空間特性と街路空間の風通し環境の関係を考察する

\section{2. 計算及び解析方法}

\section{1 計算の概要}

大阪の中心市街地を対象として CFDによる数値計算を行った. 図 1 に解析対象地域を示す. 太線で囲まれた領域を解析対象とし, そ の大きさは東西 $3,600 \mathrm{~m}$, 南北 $2,700 \mathrm{~m}$ である. 計算負荷との関係に より,この領域を $900 \mathrm{~m}$ 四方の 12 領域に分割した. この中の一領域 を例として, 計算領域の平面図を図 2 に示寸.太線の枠内が解析対 象領域であり, その周辺を含めて計算対象領域に設定した。 さらに 外側の緩衝領域にも建物群を設定した。水平方向の格子問隔は, 解 析対象領域内で $2.5 \mathrm{~m}$, その周辺で $5 \mathrm{~m}$ とし, さらに外側は徐々に広 がる不等間隔とした. 鉛直方向の格子間隔は, 解析対象地域内の最 高建物高さまでを $1 \mathrm{~m}$ ，それ以上は徐々に広がる不等間隔とした。

計算には標準 $\mathrm{k}-\varepsilon$ 型 2 方程式モデルを用いた．流入境界条件は基 準高さ $47 \mathrm{~m}$ （大阪管区気象台風速計老想定）の風速を $4.5 \mathrm{~m} / \mathrm{s}$ （風向 西）として $1 / 4$ べき莱則により与えた. 流出境界は自由流入出条件, 上空, 側面境界は free-slip 条件, 地表面, 壁面境界は一般化対数 条件とした ${ }^{3)}$. なお， 補足計算として実施した整列配置街区モデル による計算にも同様の計算方法を用いた

\section{2 解析方法}

道路の方向は, 主風向との関係に基づき, 平行道路, $22.5^{\circ}$ 道路, $45^{\circ}$ 道路, $67.5^{\circ}$ 道路, 直交道路, 交差点に分類した. $\pm 11.25^{\circ}$ の 範囲に含まれる道路を各道路分類に含めた。道路幅はGIS 上で道路 に沿って $5 \mathrm{~m}$ 毎に計測して分類した. 道路に沿ってオープンスペース が存在する場合には, 道路に沿った両隣（5m離れた地点）との関係 に基づき道路境界線を設定した，道路幅を規定した後に直交する道 路の交差部分を交差点とした. 周辺の建物高さは, 道路に沿った $5 \mathrm{~m}$ の区間の道路両側の建物高さの面積荷重平均により算出した．道路 に沿ってオープンスペースが存在する場合には, 建物高さを $0 \mathrm{~m}$ とし た. 高さ $2 \mathrm{~m}$ の風速の計算結果を高さ $47 \mathrm{~m}$ の流入風速 $(4.5 \mathrm{~m} / \mathrm{s})$ で除 した風速比を風通しの指標とする. 地区平均の風通しの考察には, 解析対象領域内から $300 \mathrm{~m}$ 四方の領域を抜き出し ${ }^{4)}$, 風速比の平均值 やグロス建蔽率等の特性値を算出する. 風上領域の特性値も同様に 抽出する.

\section{3. 計算結果の考察}

3. 1 主風向と道路方向の関係が街路空間の風通しに及ぼす影響 主風向との関係に基づき分類した道路ごとの平均風速比を表 1 に 示す，大阪市内の街路は東西及び南北の碁盤目状になっており，主 風向の西風に対して平行及び直行する道路の比率が大きい，样々な 道路幅及び周辺建物高さを含んだ集計結果ではあるが，地区全体の 平均風速比 0.27 に対し, 平行道路及び交差点において若干大きな風 速比となっている．ちなみに，村上らによって提案された気温を考 慮した風環境評価尺度を用いて大阪の夏季における弱風による非適 風の条件を評価すると 0.16 以下（強風は 0.64 以上）となり，平均 值では適風の範囲となる.

補足計算として，大阪の中心市街地の街区形態を参考に $80 \mathrm{~m}$ 四方 の整列配置街区を想定し, 流入風向, 道路幅, 建物高さをパラメー タとして計算した結果の例を図 3 に示す. 図 4 に整列配置街区モデ

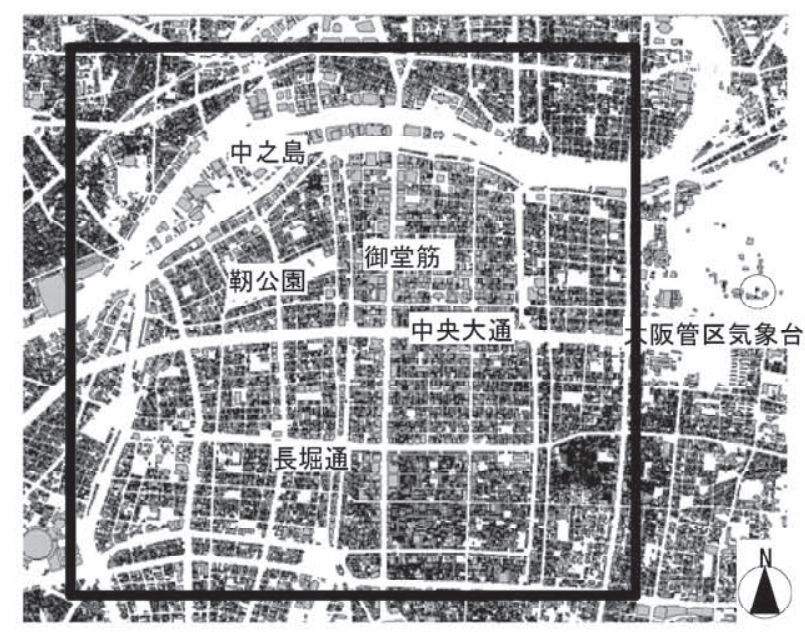

図 1 解析対象領域 (太線内の東西 $3,600 \mathrm{~m}$, 南北 $2,700 \mathrm{~m}$ )

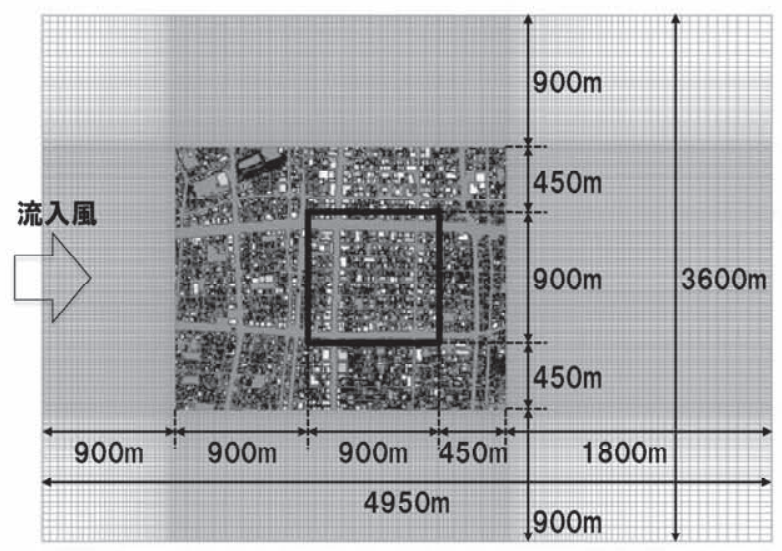

図 2 計算領域の平面図（太線内が解析対象領域の $900 \mathrm{~m} \times 900 \mathrm{~m}$ )

表 1 主風向との関係に基づき分類した道路ごとの平均風速比

\begin{tabular}{c:ccc}
\hline 道路分類 & 平均風速比 & 標淮偏差 & デー夕数 \\
\hline 平行道路 & 0.29 & 0.22 & 123,217 \\
$22.5^{\circ}$ 道路 & 0.23 & 0.18 & 15,684 \\
$45^{\circ}$ 道路 & 0.25 & 0.18 & 6,589 \\
$67.5^{\circ}$ 道路 & 0.20 & 0.16 & 17,230 \\
直交道路 & 0.24 & 0.16 & 115,857 \\
交差点 & 0.31 & 0.21 & 73,812 \\
\hline
\end{tabular}




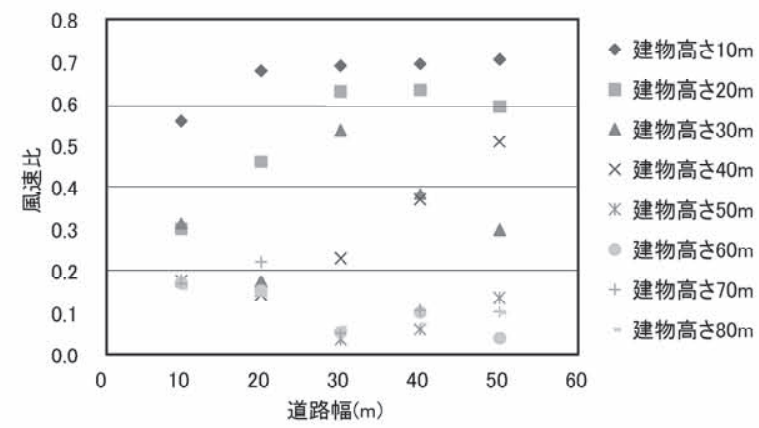

図 3 建物高さごとの平均風速比（平行道路）

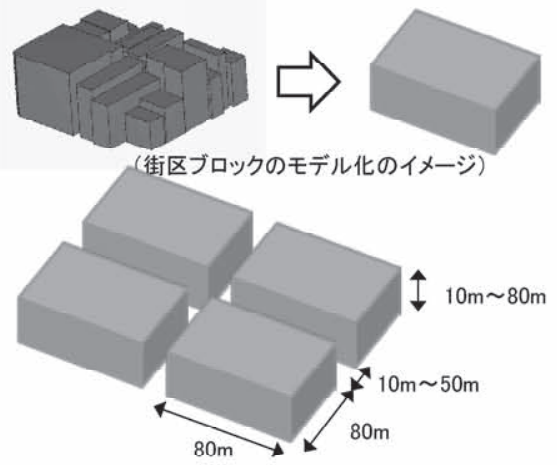

図 4 整列配置街区モデルの概要

ルの概要を示す、幾つかの建物により形成される $80 \mathrm{~m}$ 四方の街区ブ ロックを基準に道路幅と建物高さを変化させるモデルとした，主風 向に平行な道路では, 街区の高さが揃っている条件では建物高さが 増加する（この計算の想定では約 $50 \mathrm{~m}$ 以上）と上空風が街路空間内 まで流入せず, 道路幅を広くしても風通しは改善されない. 主風向 に直交する道路では, アスペクト比（道路幅と建物高さの比）によ り渦の発生状況が異なり, この渦の発生状況によって地表付近の風 通しが影響されることなどが考察された ${ }^{9)}$. 主風向と $22.5^{\circ}$ の角度 を持つ平行道路に近い道路では, 街路空間内で生じた渦と交差点か ら流れ込む風が相互に影響し風速比は減少する. 主風向と $67.5^{\circ}$ の 角度を持つ直交道路に近い道路では, 渦の性状が変化するアスペク ト比が若干異なるが，直交道路と同様の傾向になる.

\section{2 道路幅が街路空間の風通しに及ぼす影響}

平行及び直交道路における道路幅と平均風速比の関係を図 5 に示 す. 平行道路では, 道路幅の拡大に伴い風通しが改善される. 幅員 $45 \mathrm{~m}$ 以上となると地区平均の風速比 0.27 を上回っている. 直交道路 でも道路幅の拡大に伴い風通しが改善されるが, その効果は平行道 路より小さい, 道路幅 $15 \sim 50 \mathrm{~m}$ で風速比が小さくなるのは, 渦が消 滅するアスペクト比に相当するためであると考察された. 主風向と $22.5^{\circ}, 45^{\circ}$ の角度を持つ道路では, 平行道路ほどではないが道路 愊の拡大に伴う風通しの改善が確認された.

\section{3 周辺の建物高さが街路空間の風通しに及ぼす影響}

平行及び直交道路における周辺の建物高さと平均風速比の関係を 図 6 に示す. 平行道路では, 建物高さの増加に伴い風通しが改善さ れる. 高さ $20 \mathrm{~m}$ 以上で地区平均の風速比 0.27 を上回っている. 直交 道路でも建物高さの増大に伴い風通しが改善されるが, 渦の発生状 況の影響を受けるため, 道路幅との比に配慮して設計することが重

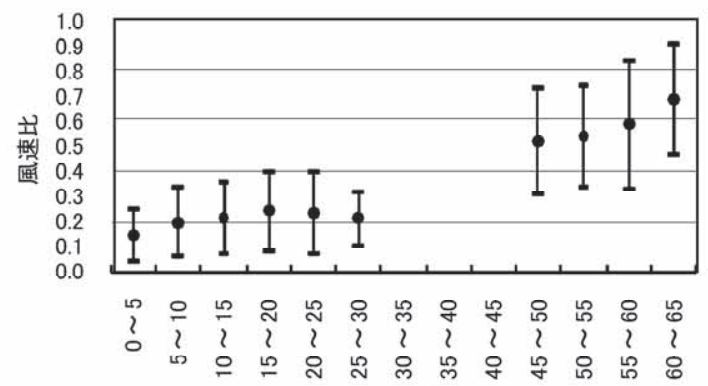

（誤差範囲は土標準偏差）道路幅( $\mathrm{m}$ )

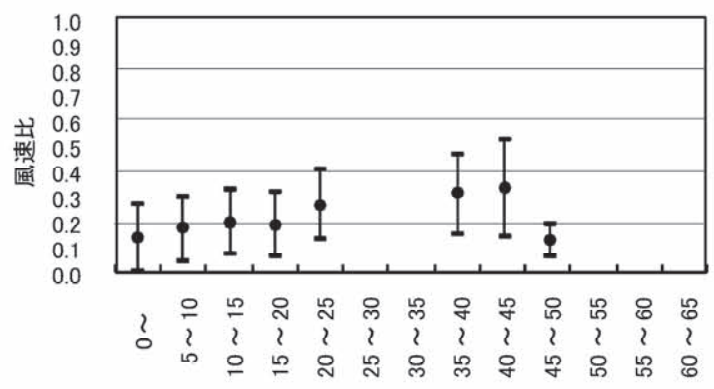

（誤差範囲は土標準偏差）道路幅 $(\mathrm{m})$

図 5 道路幅と平均風速比（上：平行道路，下：直交道路）

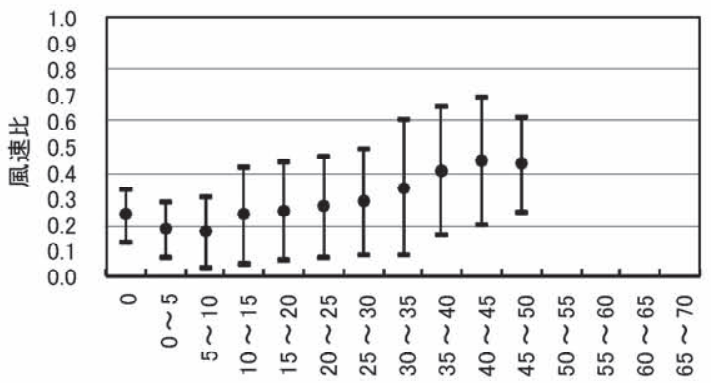

（誤差範囲は土標準偏差） 道路周辺の建物高さ $(\mathrm{m})$

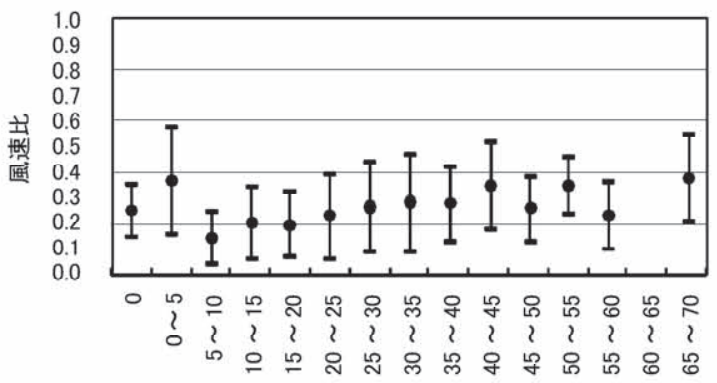

（誤差範囲は土標準偏差） 道路周辺の建物高さ $(\mathrm{m})$

図 6 周辺の建物高さと平均風速比（上：平行道路, 下 : 直交道路）
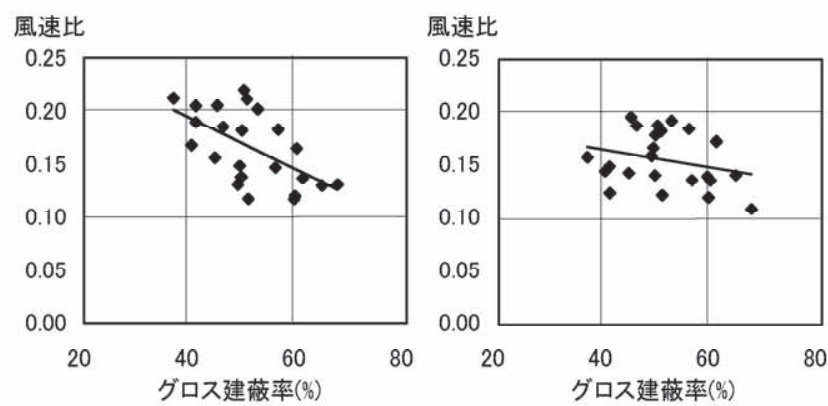

図 7 グロス建蔽率と平均風速比（左：平行道路，右：直交道路） 

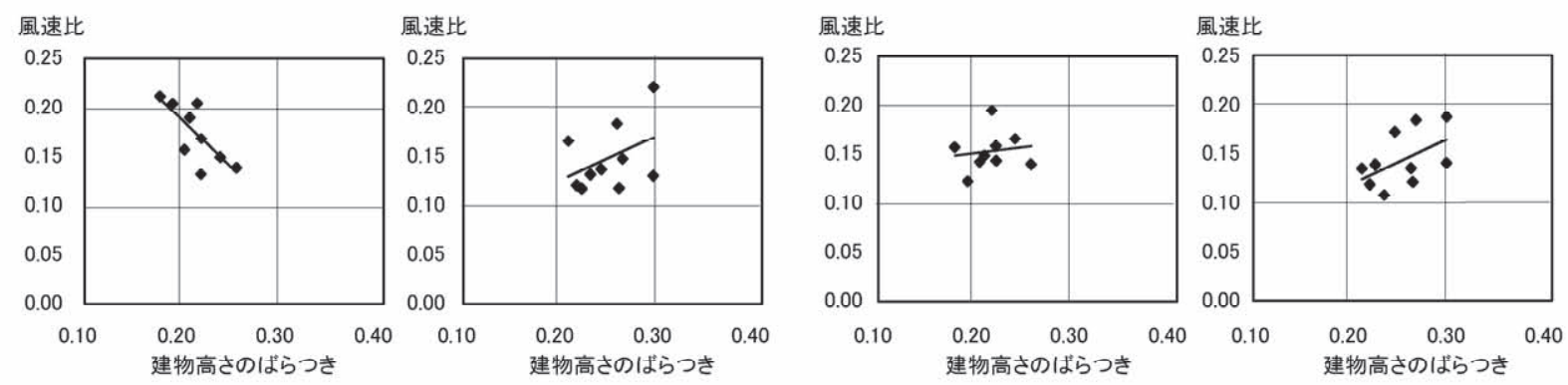

図 8 建物高さのばらつきと平均風速比（左から，平行道路のグロス建蔽率 50\%未満，同 $50 \%$ 以上，直交道路の $50 \%$ 未満，同 $50 \%$ 以）

要である. 周辺の建物高さは, 道路に沿った $5 \mathrm{~m}$ の区間の道路両側の 建物高さの面積荷重平均により算出されたため, 道路の両側にオー プンスペースが存在する場合には建物高さ $0 \mathrm{~m}$, 片側や一部に存在す る場合には建物高さ $0 \sim 5 \mathrm{~m}$ と判別される場合が多い. 直交道路にお いて片側にオープンスペースが存在するとその部分に風が通りやす くなり, 風速比が大きくなっていると解釈される. 街区内にオープ ンスペースを設けることで風通しの改善が図られる可能性を示して いる. ただし, 標準偏差が大きいため, 周辺建物との関倸によりビ ル風のように強風となっている場合があることも示唆している.

\section{4 グロス建蔽率が街路空間の風通しに及ぼす影響}

平行及び直交道路におけるグロス建蔽率と地区平均風速比の関係 を図 7 に示す. グロス建蔽率の増加に伴い風通しは悪化する. その 影響は直交道路より平行道路で顕著に表れる。グロス建蔽率が同程 度で風速比が異なる街区の状況を確認したところ, 広幅員の道路を 有し道路幅にばらつきの大きい街区で地区平均風速比が大きいこと が考察された.

\section{5 建物高さのばらつきが街路空間の風通しに及ぼす影響}

建物高さのばらつき指標として式（1）を用いる．平行及び直交道 路における建物高さのばらつきと地区平均風速比の関係を図 8 に示 す. 便宜的にグロス建蔽率 $50 \%$ 未満と以上に分類して示している. グロス建蔽率が小さい街区では建物高さのばらつきの増加による風 通しの改善は確認されず, 平行道路では地区平均風速比が小さくな る. 建物高さのばらつきにより生じる渦の影響により, 平行道路に 沿って流れてきた風が弱められる場合があると考察された。建物が 密集した地域で建物高さにばらつきを与えることは街路の風通し改 善に有効であるが，オープンスペースが適度に確保された地域では ばらつきを与える必要性は低いといえる.

$$
\text { 建物高さのばらつき }=\frac{\sum_{i}^{n} S_{i}\left|h_{m e}-h_{i}\right|}{S \cdot h_{m w}} \quad h_{m}=\frac{\sum_{i}^{n} S_{i} \cdot h_{i}}{\sum_{i}^{n} S_{i}}
$$

ここで, $S_{i}$ : 各建築面積 $\left(\mathrm{m}^{2}\right), S$ : 敷地面積 $\left(\mathrm{m}^{2}\right), h_{i}$ : 各建物高さ $(\mathrm{m})$, $h_{a v e}$ : 面積加重平均建物高さ (m), $n$ : 対象地区の建物戸数 (戸).

\section{4. 風上側街区の影響を考慮した考察}

\section{1 整列配置一様高さモデルによる考察}

補足計算として実施した風上及び対象領域の高さが一様な整列配 置街区モデル（大阪の中心市街地の街区形態を参考に, 街区 $80 \mathrm{~m}$ 四 方, 道路幅 $15 \mathrm{~m}$, 建物高さ $20 \sim 80 \mathrm{~m}$ 間で $10 \mathrm{~m}$ 毎に変化）の計算結果 より, 風上領域と対象領域の高さの差（対象一風上）と対象領域の 平均風速比の関係を図 9 に示寸.街区モデルの概要は図 4 と同じで, 対象領域と風上領域の設定を図 10 に示す.高さの差が大きいほど平

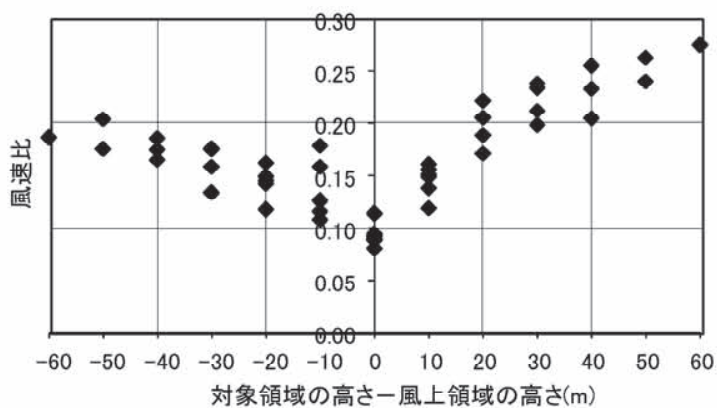

図 9 高さの差（対象領域一風上領域）と対象領域の平均風速比

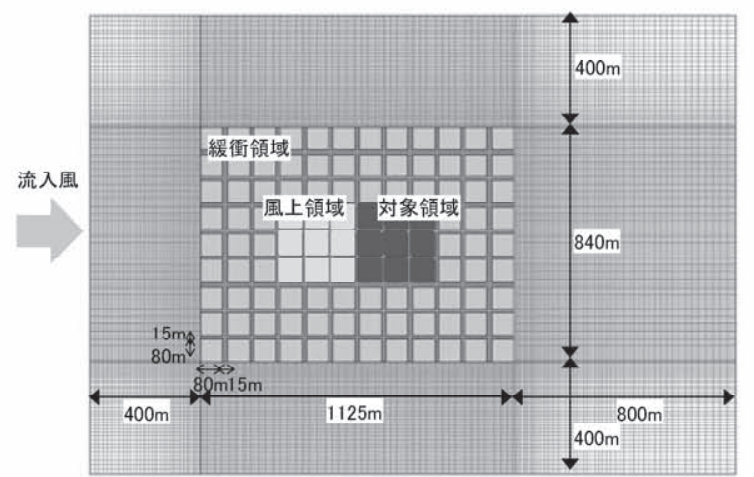

図 10 整列配置街区モデルの計算領域と対象領域，風上領域

均風速比が大きい，特に，対象領域が風上領域上り高い場合に影響 が大きい，対象領域が高い場合には吹きおろしの風により平行道路 と交差点で風速比が大きくなり, 風上領域が高い場合には刘象領域 が負圧域になるため逆流する向きに風速比が大きくなっている.

\section{2 整列配置ばらつき高さモデルによる考察}

整列配置街区モデル（街区特性は 4.1 と同様）の高さのばらつき として図 11 に示す平行, 直交, 千鳥配置を想定した. 対象領域及び 風上領域の平均建物高さ之対象領城の平均風速比の関係を図 12 に 示寸．風上領域の平均建物高さ及びそのばらつきパターンの影響は 小さい. 対象領域の高さを平行配置でばらつかせても一様配置と同 様に平均建物高さが増大しなければ風通しは改善されないが，直交 または千鳥配置でばらつかせると平均建物高さが小さくても風通し が改善する．このときの街区内の風ベクトルの様子を確認したとこ ろ，建物高さが大きい街区の風上側の直交道路に上空風が引き込ま れて周辺に広がり, 負圧域になった風下側の直交道路にも周辺から 風が引き込まれる様子が確認された. 成田 ${ }^{10)}$ や萩島ら ${ }^{6)}$ が指摘して いるように, 不均一な建物高さの場合に正圧域, 負圧域が適度に形 
成され風通しの改善に繋がっていると考察された.

\section{3 実街区モデルによる考察}

街区における 3 次元的な建物の密集度合を示す指標として, 義江 ら ${ }^{5)}$ は高さ方向平均グロス建蔽率を用い, 街区全体の平均的な風通 しと負の相関があることを明らかにしている. 本研究でも同様に高 さ方向平均グロス建蔽率を用いる. ただし, 高層建物の上層部分が 地表付近の風通しに及ぼす影響は小さいため, 評価する基準高さに 平均建物高さを用いた高さ方向平均グロス建蔽率 (平均建物高さ基 準) を用いる (式 (2) 参照).

$$
\lambda_{a c}=\frac{1}{h_{a v e}} \int_{0}^{h_{a v}} \lambda(z) d z
$$

ここで, $\lambda_{a c}$ : 高さ方向平均グロス建蔽率 (平均建物高さ基準), $h_{a v e}$ : 街区内の平均建物高さ $(\mathrm{m}), \lambda(\mathrm{z})$ : 高さ $z$ における建物群水平断面 積が街区全体の面積に占める割合.

対象領域及び風上領域の高さ方向平均グロス建蔽率（平均建物高 さ基淮）と対象領域の平均風速比の関係を図 13 に示す. 対象領域及 び風上領域ともに高さ方向平均グロス建蔽率（平均建物高さ基準） が増加すると対象領域の平均風速比は低下-子る。 なお，この傾向は 最高建物高さを基準とした高さ方向平均グロス建蔽率を指標とした 場合より顕著に確認された. 街路空間の風通しは, 対象領域だけで なく風上領域の街区特性の影響も受けており, 歩行者レベルよりあ る程度上層の空間の建物群が高密度になると風通しは悪くなる.

以上より, 街路空間の風通しを改善するには, 高さ方向平均グロ 又建蔽率 (平均建物高さ基準) を小さくすることが有効であり，建 築面積の小さい高層建物が適度に配置されることも対策の一つであ るといえる.

\section{5. まとめ}

考察対象街路周辺の街路形態だけでなく, 幾つかの建筑物により 形成される街区の特性が, 街路空間の風通し環境に及ぼす影響につ いて, 風上領域の街区による影響も含めて, 大阪の中心市街地を対 象とした CFD による数值計算の結果に基づき検討を行った.

整列配置街区モデルでは, 建物高さが揃った条件での検討となる ため, 建物高さが増大すると上空風が街路空間内まで流入しない結 果となった．しかし，建物高さにばらつきを有する実街区モデルの 検討結果では, 建物高さが増大すると風通しが改善される傾向が確 認された。 そこで, 実街区モデルにおいてグロス建蔽率, 建物高さ のばらつきを指標として街路空間の風通しとの関係を分析したとこ ろ, グロス建蔽率が大きく建物が密集した地域で建物高さにばらつ きを与えることは有効であるが，オープンスペースが適度に確保さ れた地域では必要性が低いと考察された。

更に, 整列配置街区モデルにより, 建物高さのばらつきの状況 (平 行, 直交, 千鳥配置) と街路空間の風通しの関倸を分析したところ, 千鳥配置のように建物の高さがばらつくことで, 街路空間内に正圧 域, 負圧域が適度に形成され風通しの改善に縏がっていると考察さ れた，実街区モデルにより，高さ方向グロス建蔽率 (平均建物高さ 基準）と街路空間の風通しの関係を分析したところ, 対象領域だけ でなく風上領域の高さ方向グロス建蔽率（平均建物高さ基準）を小 さくすることが,街路空間の風通し改善に有効であると考察された.

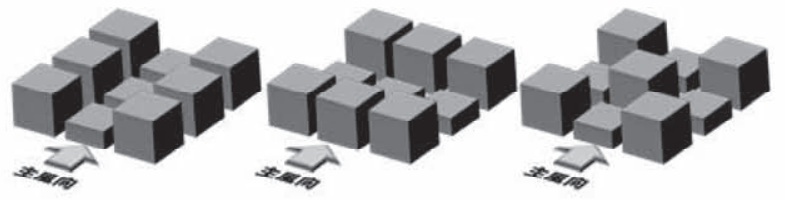

図 11 平行 (左), 直交 (中), 千鳥配置（右）高さばらつきモデル
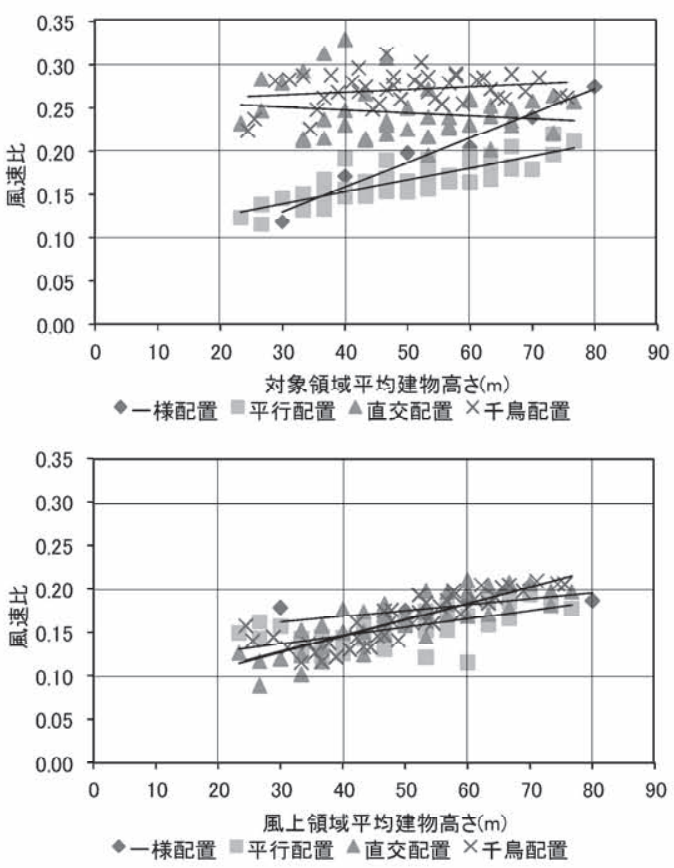

図12平均建物高さと対象領域の平均風速比

（上：対象領域が変化した場合,下：風上領域が変化した場合）
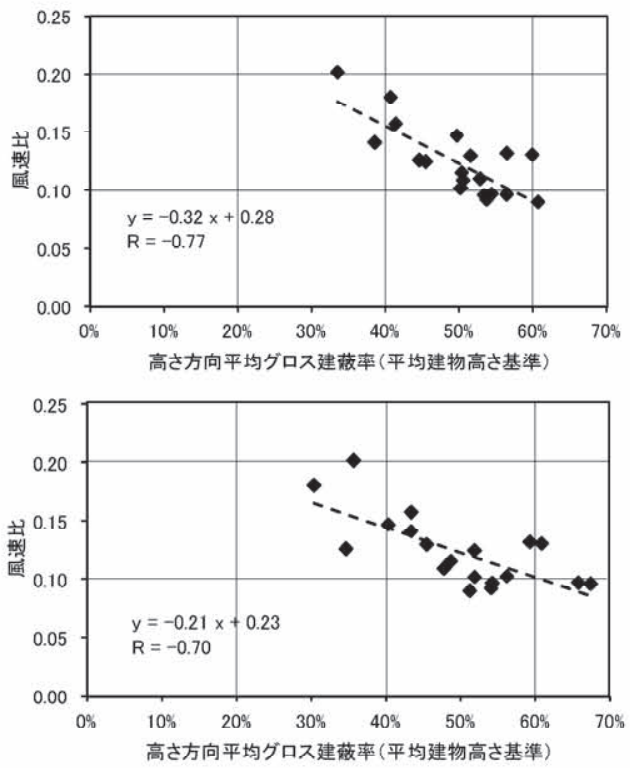

図 13 高さ方向平均グロス建蔽率（平均建物高さ基準）と 対象領域の平均風速比(上: 対象領域の高さ力向平均分口ス建蔽率, 下: 風上領域の高さ方向平均グロス建蔽率)

\section{謝辞}

本研究で使用した建物データは大阪市より提供頂きました．本研 究の一部を修士論文として取組まれた増田恭大氏に謝意を表します。 


\section{参考文献}

1）竹林英樹, 森山正和：上空気象データを用いた海風による気温低下効果の 考察, 日本建築学会環境系論文集, 第 643 号, pp. 1099-1105, 2009.9

2）竹林英樹, 森山正和, 三宅弘祥 : 気候資源としての風の利用を目的とした 街路形態と街路空間の風通しの関係の分析, 日本建築学会環境系論文集, 第 635 号, pp. 77-82,2009.1

3) 日本建築学会: 市街地風環境予測のための流体数值解析カイドブックーガ イドラインと検証用データベースー, pp. 156-163, 日本建築学会, 2007.7

4) 久保田徹, 三浦昌生, 富永禎秀, 持田灯: 実在する $270 \mathrm{~m}$ 平方の住宅地に おける地域的な風通しに関する風洞実験, 建築群の配置・集合形態が地域 的な風通しに及ぼす影響その 1, 日本建築学会計画系論文集, 第 529 号, pp. 109-116, 2000.3

5）義江龍一郎, 田中英之, 白澤多一, 小林剛：高層密集市街地における建物 群の形態が歩行者レベルの風速・気温分布に与える影響, 日本建築学会環 境系論文集, 第 627 号, pp. 661-667,2008.5

6) 萩島理, 谷本潤, 末永啓, 池谷直樹, 前田一行, 成田健一：直方体粗度群 の床面バルクスカラー係数に関する風洞模型実験, 日本建築学会環境系論
文集，第 632 号, pp. 1225-1231，2008.10

7）栗田剛，大場正昭：一様建物高さ分布で直列配置された街区におけるグロ ス建蔽率が熱輸送と運動量輸送に及ぼす影響について, 暑熱化都市キャノ ピ一層の熱輸送特性に関する実験的研究（その1), 日本建築学会環境系論 文集，第 652 号, pp. 509-515，2010.6

8）足永靖信，東海林孝幸，河野孝昭：地球シミュレー夕を用いた東京都心 $10 \mathrm{~km}$ 四方における高解像度のヒートアイランド数值解析, 日本建築学会環 境系論文集，第 616 号, pp. 67-74, 2007.6

9）山田俊明, 竹林英樹, 森山正和: 街路形態が街路空間の風通し環境に及ほ 寸影響に関する研究, 日本建築学会大会学術講演梗概集, D-2, pp. 769-772, 2010. 9

10）成田健一：都古内河川の微気象的影響範囲に及ぼす周辺建物配列の影響 に関寸る風洞実験, 日本建築学会計画系論文集, 第 442 号, pp. 27-35, 1992. 12

（2011年 4 月25日原稿受理，2011年 9 月 7 日採用決定） 